\title{
Guarapiranga Reservoir-Pharmaceuticals and Historical Urban Occupation in a Water Source
}

\author{
H. M. Shihomatsu' ${ }^{1}$, E. A. J. Martins ${ }^{1}$, M. E. B. Cotrim¹, D. T. Lebre' ${ }^{2}$ N. Ortiz ${ }^{1 *}$, M. A. F. Pires ${ }^{1}$ \\ ${ }^{1}$ Institute for Nuclear and Energy Research-IPEN, São Paulo, Brasil \\ ${ }^{2}$ Centro de Espectrometria de Massas Aplicada Ltda., São Paulo, Brasil \\ Email: *nortizbr@gmail.com
}

How to cite this paper: Shihomatsu, H.M., Martins, E.A.J., Cotrim, M.E.B., Lebre, D.T., Ortiz, N. and Pires, M.A.F. (2017) Guarapiranga Reservoir-Pharmaceuticals and Historical Urban Occupation in a Water Source. Journal of Geoscience and Environment Protection, 5, 1-17.

https://doi.org/10.4236/gep.2017.513001

Received: September 19, 2017

Accepted: December 25, 2017

Published: December 28, 2017

Copyright ( 2017 by authors and Scientific Research Publishing Inc. This work is licensed under the Creative Commons Attribution-NonCommercial International License (CC BY-NC 4.0).

http://creativecommons.org/licenses/by-nc/4.0/

\begin{abstract}
The pharmaceutical compounds were analyzed in 14 sampling sites and pointed out the pollution sources related to raw sewage input and urban drainage discharge. Five medicine compounds, one illicit drug, and its metabolite were the higher measured content using analytical improvements tailored to identify and quantify organic compounds in low water content. The use of SPE cartridges followed by liquid chromatography with tandem mass spectrometry (LC-ESI-MS/MS) points out the Guavirutuba tributary as the primary water pollution source with higher concentrations in 2011 for pharmaceuticals, cocaine, and benzoylecgonine (metabolite) in the range of $6.7 \pm 0.9 \mathrm{ng} \mathrm{L}^{-1}$ to $27.386 \pm 142 \mathrm{ng} \mathrm{L}^{-1}$. The Jaceguay stream also located in Guarapiranga was the most preserved area and provided analytical values correspondent which lowered contamination content. Such concentrations mean a possible and feasible water restoration target. The most common compounds (above $90 \%$ samples) were: caffeine, atenolol, carbamazepine, cocaine, and benzoylecgonine. The integrated risk index for aquatic chemical pollution (IRICAP) confirms the higher contamination near Guavirutuba stream and the lower near the Jaceguay stream. Published results of cocaine and benzoylecgonine content in Guarapiranga basin corroborated with the analytical results.
\end{abstract}

\section{Keywords}

Guarapiranga, Guavirutuba, Illicit Drug, LC-MS/MS, Pharmaceuticals

\section{Introduction}

The São Paulo Metropolitan Area (SPMR) is the most significant metropolitan area of the South America Continent, actually with 20,935,204 million of inhabitants [1], and the highly financial, industrial and commercial capital of Brazil. How- 
ever, the potable water supply of the capital city is about $150 \mathrm{~m}^{3} /$ inhabitant/year, seven times smaller than the critical value of $1500 \mathrm{~m}^{3} /$ inhabitant/year, considered adequate by the United Nations.

The Guarapiranga reservoir is the second largest water source in São Paulo Metropolitan Area and responsible for 14,000 liters/second of potable water supply to 4 million inhabitants [2]. Even nowadays the information on behavior and presence of emerging pollutants in the reservoir is scarce. In 2015, a severe drought started the worst water crisis in 80 years. During such period the Guarapiranga reservoir, as a result of its particular geography, was less threatened for water scarcity and kept the water supply in a reasonably safe level with potable water sustainability and production [3]. The public water reservoir has a drainage area of 638 $\mathrm{km}^{2}$ and is fully inserted in Metropolitan Area of São Paulo, belonging to many municipalities of São Paulo State. In many ways, the basin area can also be considered as water municipality transboundary pollution.

The background of the Guarapiranga reservoir represents a vital water source with relevant ecological and environmental role ensuring climate balance in the southern metropolitan urban area. In spite the São Paulo state Law number 12,233 from January 2006 which defines Guarapiranga Basin as natural preserved area, historically the basin have been threatened by urban growth with the unplanned occupation, Figure 1 [4].

The environmental legislation not included yet the emerging pollutants in spite their detection widely, mostly in related to surface, groundwater and drinking water. The official monitoring programs that address the determination of these contaminants are scarce. The regulatory agencies as EPA and European Union (EU) take some groundbreaking actions in this direction, and 1998 announced the first Drinking Water Contaminant Candidate List (CCL1) establishing a list of 50 chemicals and 10 microbial contaminants. They were a priority to regulate the information collections and decision-making regarding the establishment of strategies to minimize the drinking water contamination. An upgrade of the contaminant list CCL 4 was proposed by EPA in 2015 and covered 100 chemicals as 12 microbial contaminants [5].

The EU promotes some strategies to achieve the reduction of water pollution compounds a final list published in 2011 includes 41 substances such atrazine, nonylphenol, octyl phenol and others. Published works indicate the caffeine as the most common organic pollutant found in Brazilian national drink waters; the frequency of the detection corresponds with $93 \%$ similar with those found in China and Spain. In Brazil nine of the 22 water analyzed Capitals showed in the range of 122 to $629 \mathrm{ng} \mathrm{L}^{-1}$, except Porto Alegre com 2659 and $2769 \mathrm{ng} \mathrm{L}^{-1}$ e Campo Grande with $899 \mathrm{ng} \mathrm{L}^{-1}$. The higher caffeine content detected in Billings water reservoir with 18,828 $\mathrm{ng} \mathrm{L}^{-1}$ and in Guarapiranga was $255 \mathrm{ng} \mathrm{L}^{-1}$ [5]. The detection of caffeine in drinking water is related to the great resistance time in the environment with a compound with less susceptible degradation. The caffeine content is directly related to sewage input in the source of water supply. 
The atrazine detection was on 16 of the 22 water samples. These obtained results were for the three are the main agricultural cities responsible for more than $80 \%$ of the total consumption of the herbicide in the country. The water reservoir analysis indicates atrazine in $15 \mathrm{ng} \mathrm{L}^{-1}$ and the bisphenol $\mathrm{A}$ in $11 \mathrm{ng} \mathrm{L}^{-1}$ in Billings, $15 \mathrm{ng} \mathrm{L}^{-1}$ Cantareira and $19 \mathrm{ng} \mathrm{L}^{-1}$ for Guarapiranga.

The information of the presence and behavior of emerging pollutants in water reservoir is scarce. In many cases where the detection of a high level of eutrophy, emerging pollutants, and pesticides. For pesticides, there were spatial and seasonal patterns in the analytical results. In Guarapiranga were detected three compounds showing possible risk for biota.

The Guarapiranga is an example of multi stressed urban reservoir located in the tropical region. In literature is cited a total of 31 organic compounds detected in the system: illicit drug, pesticide, pharmaceutical and endocrine disruptors. The most contaminant found were pesticides usually in dry season, emerging pollutants and chlorophyll and an indication of Trophic State index [6]. The project also provides some monitoring results to promote and establish acceptable limits for water quality control and regulations.

The three groups of contaminants EPS, pesticides and nutrients is a result of different sources and not always correlated. No risk is observed in raw water from water catchment site in spite of pollution gradient between the lower part and the upper part of the Guarapiranga basin with no danger for water drinking use, but the carbendazim, imidacloprid, and BPA content showed risks for biota [6].

In literature is described the challenges of the experimental work and the demanding of the analytical methodology for measure the organic pollutants in such low concentrations. The filtration was the first step of the analytical procedure for water samples followed by the concentration, extraction, and measurement using liquid chromatography-tandem mass spectrometry (LC-MS/MS) and electrospray ionization source (ESI) operated in negative and positive mode.

Many studies and monitoring results indicate the municipalities and neighborhoods within the Guarapiranga catchment with poor sewage water collection and treatment. Less than $50 \%$ of the wastewater is collected and treated resulting in a hypereutrophic scenario. The illicit drug contamination was also measured showing high correlation with phosphate content an indication of drug use and sewage discharge.

The environmental degradation of Guarapiranga basin started before 1932, but it was considered with little environmental impact and received no further attention from the scientists, government, and users. Nerveless, after 1932 the urban pressure increases and started to pose a threat to water quality maintenance. Nowadays the unplanned urban expansion with spatial and seasonal patterns with high levels of eutrophy and emerging pollutants were detected. Additionally, the urbanization impacted the ecosystems, changing the water courses direction, deforestation, and evidence of soil exposition.

The novelty of the project was the determination of the direct relationship between water quality monitoring results and the historical economic profile of the 
Guarapiranga reservoir. The industrialization development and the urban growing impact with water quality loss. The scenario of urban environmental impact studies can be generalized and share many common aspects with emerging economies all over the world.

\section{Materials and Methods}

The urban development in Guarapiranga basin was increasing with the industries in the northern part mostly in 30's and 40's years resulting in deforestation process, soil exposition and loss. The monitoring point near Guavirutuba tributary was essential due to its northern geographical location; the urban creek can be considered the first step of the urban expansion with water quality loss caused by sewage and urban drainage discharge. In other hand published studies indicate the sampling point near Jaceguay stream as an example of an environmentally preserved area, its higher distance from the city center apparently reduced the public pressure and the water quality loss, Figure 1 and Figure 2.
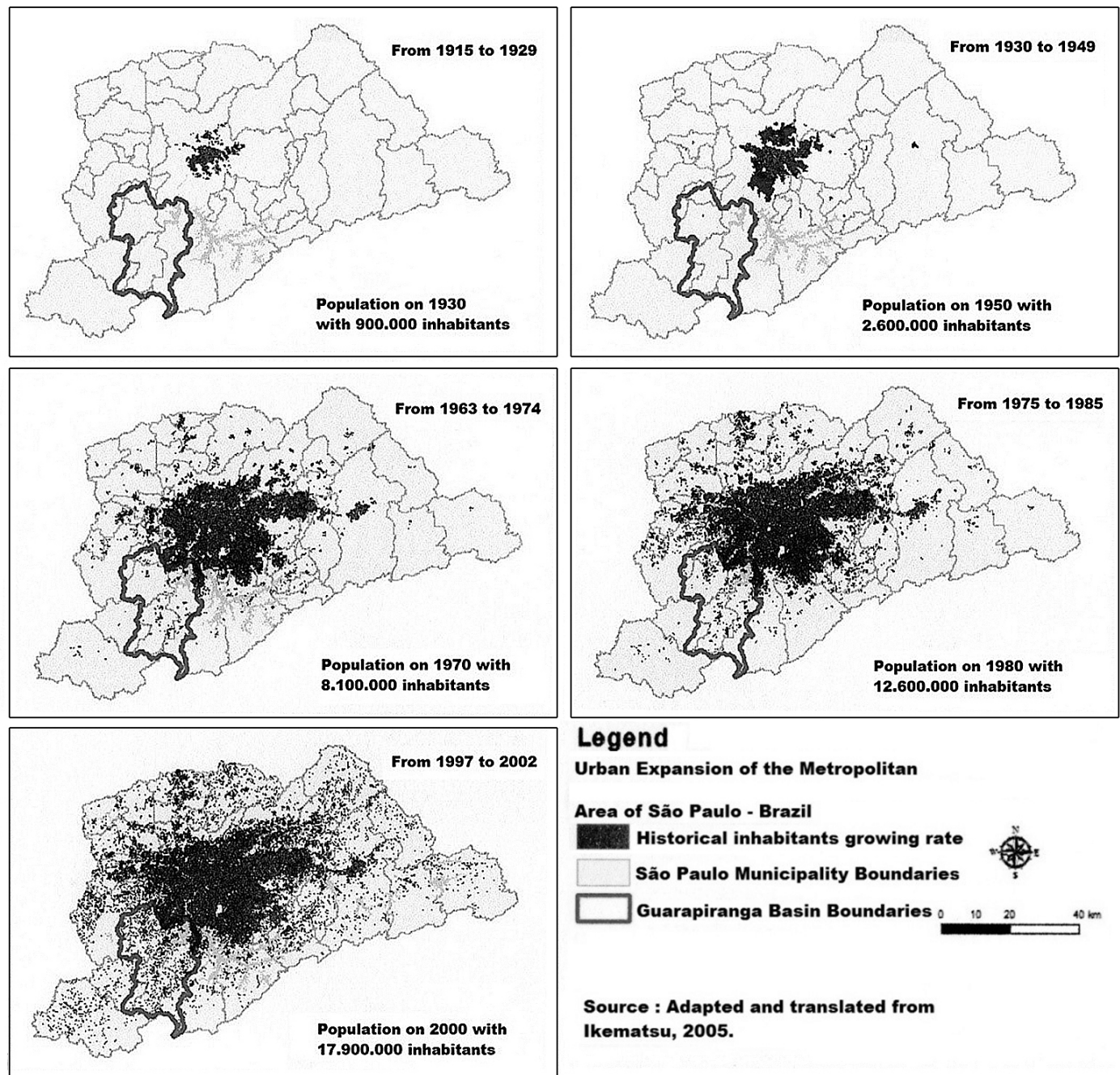

\section{Legend}

Urban Expansion of the Metropolitan

Area of São Paulo - Brazil

Historical inhabitants growing rate

São Paulo Municipality Boundaries

Guarapiranga Basin Boundaries 0 $10 \quad 20 \quad 40 \mathrm{~mm}$

Source : Adapted and translated from Ikematsu, 2005.

Figure 1. The urban expansion historical profile of Guarapiranga basin. Adapted and translated from Ikematsu, 2005 [7]. 


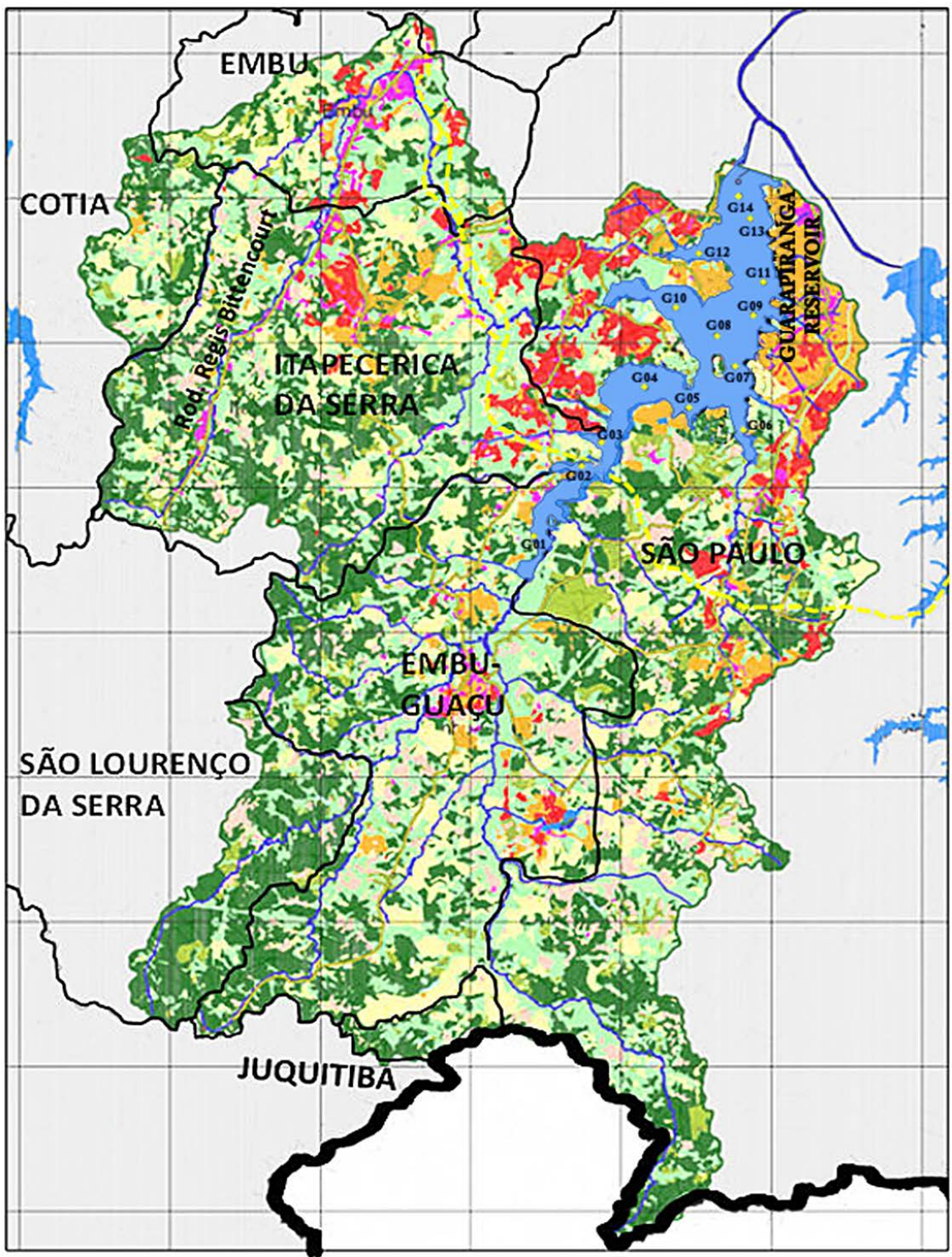

\section{Legend - Guarapiranga soil occupancy}
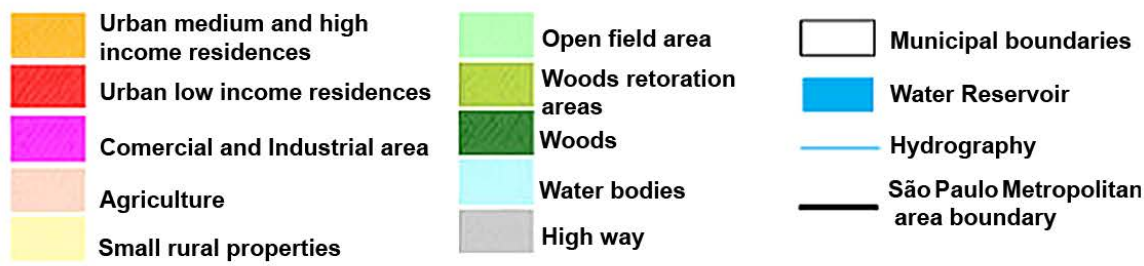

Source : Adapted and translated from Ikematsu, 2005.

Figure 2. The soil occupancy of the Guarapiranga basin and the water sampling sites [7].

The right margin tributary with high water volume is Parelheiros River, in left margin are Embu-Guaçu and Embu-Mirim (Figure 2). The others streams and watercourses, in spite of low water volume, have been performed a significant role in water pollution input, mostly from raw sewage discharge and urban drainage system. The comparison between the Guavirutuba stream (G12) consi- 
dered the most polluted watercourse and the Jaceguay stream (G05) located near a preserved area with high water quality provides a significant pollution diagnosis and a target information about the restoration possibilities to be used by government, shareholders, and users. The monitoring results are meaning a possible and feasible goal to pose a directive to pollution reduction in this valuable water resource.

In 2012 the state government started the transposition of Taquacetuba River to promote the water connection between Billings reservoir and Guarapiranga basin, such additional water volume was an effort to improve the Guarapiranga water quality and quantity. After the transposition, the water quality has been enhanced, confirmed by the monitoring results measured in sampling sites G05, G06 and G07 located closer of the water pipes addition. Such improvement was also confirmed in lower degree on sampling sites G14 and G13 with less pollution indication.

In 2015 the State Government of Sao Paulo in collaboration with World Bank for Latin America-BIRD built a sewage collection pipes in the northern limits of Guarapiranga basin, adjacent streets, and avenues with historical unplanned urban expansion. Nowadays there is also another planned project to improve the Guarapiranga water quality catchment; the ultrafiltration membrane system will be installed near the water catchment area (G14) to reduce the urban drainage pollution in Guarapiranga basin.

The pharmaceuticals production is essential and responsible for life quality improvement, the public health, life expand and perform a significant role in prevention, diagnostic and treatment in human and veterinary medicine. The human aging tendency also indicates the increase of pharmaceuticals production and consumption trend shortly. Published environmental studies had demonstrated the raw sewage discharge and urban drainage wastewater as the main routes and sources of pharmaceuticals input in the aquatic environment [7] [8].

About $50 \%$ to $90 \%$ of the administered medicines are excreted in their active forms or metabolized in urine and feces of domestic sewage, dispersing and persisting in significant extent into the environment. Such pollution intake meanings potential risk to the water quality, to the environment, human and animal health [9] [10]. Many published works related the identification and quantification of pharmaceutical compounds in surface water resources, like lakes and Rivers in many parts of the world [11].

The liquid chromatography with tandem mass spectrometry (LC-MS/MS) is the most useful analytical technology tailored for water quality monitoring with the identification and quantification of pharmaceuticals and organic contaminants in low levels. The LC-MS/MS technique is highly sensitive. However, the sample preparation is very demanding for small concentration limits for quantification [12].

In this context, the Project was the quantification of pharmaceutical compounds and illicit drugs in different water sampling sites of Guarapiranga basin. The mon- 
itoring sites were chosen considering the historical profile of unplanned urban occupation. The comparison of the results obtained in the most polluted area, near Guavirutuba tributary with high pollution and high clogging effects with Jaceguay tributary water monitoring located in the most preserved area with little clogging effects is presenting in Table 1.

Table 1 shows the clogging index as pollution intake indication for Guavirutuba during passing decades, as an apparent result of the urbanization growth and the water quality loss. The location of Jaceguay tributary far from the urbanization wave showed lower clogging indication with high water quality during decades. The clogging indication measurements represented the Guarapiranga water level and the values obtained in different decade's shows just a little difference. The reservoir water volume was kept almost constant and not interfering in the measured clogging values.

The clogging indication is an effect of water pollution intake which includes high impact by soil loss, silting and high deforestation degree. The clogging rates for Guavirutuba tributary were higher after 1986 with the presence of soil dumping areas, building houses, streets, and avenues. On the other hand, in the Jaceguay tributary was observed little-clogging indication, in 1986 as an isolated event of clogging increase was a result of the agricultural activity with soil exposition, such effect was reduced from 1994 to 2000 when started the environmental restoration. The Guavirutuba in Figure 1 represents the first step of the ecological impact of the urbanization grow and the primary pollution source, Figure 2 and Table 1.

Table 1. Clogging indication from polluted Guavirutuba and the preserved Jaceguay tributary (Adapted and translated from Silva 2005) [4].

\begin{tabular}{|c|c|c|c|c|c|}
\hline \multirow[b]{2}{*}{ Year } & \multicolumn{3}{|c|}{ Guavirutuba } & \multirow[b]{2}{*}{$\begin{array}{c}\text { High-Density } \\
\text { Urbanization } \\
\text { (\%) }\end{array}$} & \multirow[b]{2}{*}{$\begin{array}{c}\text { Guarapiranga } \\
\text { Water Level } \\
\text { (m) }\end{array}$} \\
\hline & $\begin{array}{l}\text { Complete and } \\
\text { Second Clogging } \\
\text { Degree }\end{array}$ & $\begin{array}{c}\text { Low-Density } \\
\text { Urbanization } \\
(\%)\end{array}$ & $\begin{array}{l}\text { Medium Density } \\
\text { Urbanization } \\
(\%)\end{array}$ & & \\
\hline 1932 & 0.39 & - & - & - & 734.13 \\
\hline 1962 & 0.63 & 12.9 & & & 735.8 \\
\hline 1972 & 1.47 & 8.9 & 54.6 & & 733.96 \\
\hline 1986 & 3.07 & 7.1 & 3.6 & 59.4 & 734.01 \\
\hline 1994 & 2.2 & 4.8 & 8.8 & 73.4 & $435.38-734.98$ \\
\hline \multirow[t]{2}{*}{2000} & 3.06 & 5.1 & 8.7 & 73.5 & 733.24 \\
\hline & & Jaceguay & & & \\
\hline 1932 & 0.061 & - & - & - & 734.13 \\
\hline 1962 & 0.62 & - & - & - & 735.8 \\
\hline 1972 & 1.18 & - & - & - & 733.96 \\
\hline 1986 & 1.57 & 11.3 & - & - & 734.01 \\
\hline 1994 & 0.78 & 7.9 & - & - & $435.38-734.98$ \\
\hline 2000 & 1.82 & 6.8 & - & - & 733.24 \\
\hline
\end{tabular}


The integrated risk index of aquatic chemical pollution (IRICAP) is a numerical indication of chemical contamination. The equation result provides a number associated with the chemical exposition risk for living organisms of surface water resources [13] (Equation (1)). The IRICAP formula is:

$$
\text { IRICAP }=\mathrm{HIi} \times \mathrm{CiN}+\mathrm{Hj} \times \mathrm{CjN}+\cdots(\mathrm{HIn} \times \mathrm{CnN})
$$

where $\mathrm{CiN}=$ The normalized concentration of compound I of a given sampling site measurement; $\mathrm{Hii}=$ hazard index of compound $\mathrm{i}$.

The HI is the calculation of large amounts of data and information for different compounds with Self-Organizing Maps (SOM) and an artificial neural network (ANN). The system prioritizes the chemical compounds with high environmental persistence, bioaccumulation and toxicity properties [13].

The water samples were collected using a horizontal Van Dorn bottle and transferred to a $4 \mathrm{~L}$ amber glass bottle, previously cleaned and decontaminated. The sample bottles were kept in coolers and transported with ice $\left( \pm 6^{\circ} \mathrm{C}\right)$. In the laboratory, the samples were filtered with $1 \mu \mathrm{m}$ glass fiber membrane followed by $0.45 \mu \mathrm{m}$ nylon membrane and kept in the refrigerator. After filtration, the monitoring compounds were extracted, concentrated and purified within seven days.

The Guarapiranga water samples analysis and results are showing in Table 2 . Polluted watercourses near urban areas usually show the medicine compounds as a nonsteroidal anti-inflammatory (acetaminophen), $\beta$-blocker (atenolol), diuretic (chlorthalidone), anticonvulsant (carbamazepine), stimulant (caffeine) and illegal drug/metabolite (cocaine/benzoylecgonine).

The solutions of acetaminophen, atenolol, caffeine, and carbamazepine were prepared with high purity ( $>95 \%)$ using standards solutions, supplied by SigmaAldrich. The Cerilliant provided the certified references for Cocaine and benzoylecgonine with high purity $(>99 \%)$. The compound chlorthalidone was prepared using the active principle of commercial medicine.

Individual standard solutions at $200 \mu \mathrm{g} \mathrm{mL}^{-1}$ were prepared in Methanol$\mathrm{MeOH} / \mathrm{HPLC}$ grade water (1:1, v/v) using $10 \mathrm{~mL}$, except for individual standard solutions of caffeine made in acetonitrile-ACN/HPLC grade water (1:1, v/v). The standard solutions of cocaine and benzoylecgonine at $50 \mu \mathrm{g} \mathrm{mL}^{-1}$ were prepared in MeOH/ACN/HPLC grade water (50:25:25, v/v/v). The storage of the prepared standard solutions was at $-20^{\circ} \mathrm{C}$. The StrataTM X $(200 \mathrm{mg}, 3 \mathrm{~mL})$ Phenomenex was used as SPE cartridge.

The pharmaceuticals quantification on five-point external calibration curves allows the organic compound measurement in reservoir water extract (in the matrix). The external calibration curves in the matrix of acetaminophen, atenolol, and benzoylecgonine were prepared in the concentration range of 5 to $200 \mathrm{ng} \mathrm{mL}^{-1}$, while the content of caffeine and cocaine was in the range of 5 to $500 \mathrm{ng} \mathrm{mL}^{-1}$ and for carbamazepine and chlorthalidone was 5 to $50 \mathrm{ng} \mathrm{mL}^{-1}$.

The ACN $(3 \mathrm{~mL})$ conditioned the Strata SPE cartridges followed by $3 \mathrm{~mL}$ of $\mathrm{MeOH} / \mathrm{Isopropanol} / \mathrm{ACN}(1: 1: 1, \mathrm{v} / \mathrm{v} / \mathrm{v})$ and $4 \mathrm{~mL}$ of HPLC grade water in a flow 
rate of $2 \mathrm{~mL} \mathrm{~min}^{-1}$. After conditioning, $250 \mathrm{ml}$ of water loaded onto the cartridge at the same flow rate, rinsed with $3 \mathrm{~mL}$ of HPLC grade water, and air dried for 10 minutes, to remove excess water. The addition $3 \mathrm{~mL}$ of MeOH/Isopropanol/ACN $(1: 1: 1, \mathrm{v} / \mathrm{v} / \mathrm{v})$ followed by $3 \mathrm{~mL}$ of ACN promoted the elution. The final extract was evaporated to dryness under a gentle air stream and reconstituted with 0.25 $\mathrm{mL}$ of ACN/HPLC grade water (5:95, v/v) and analyzed by LC-ESI-MS/MS.

LC analysis was performed using an Agilent HPLC equipped with a quaternary pump, degasser (model 1260), column oven and automatic injector (Model 1290). The Chromatographic separation used a reverse phase column Eclipse XDB-C18 $(50 \mathrm{~mm} \times 4.6 \mathrm{~mm}$, pore size $1.8 \mu \mathrm{m}$ ) from Agilent (USA), $10 \mu \mathrm{L}$ sample injection, $700 \mu \mathrm{L} \mathrm{min}{ }^{-1}$ flow rate. The column temperature kept at $25^{\circ} \mathrm{C}$ with the positive ion mode analysis (ESI+) used formic acid $0.1 \%$ in HPLC grade water, and the eluent B was ACN. The elution started with $95 \%$ of eluent A, decreasing linearly to $5 \%$ in 5 minutes. The condition was held for 1 minute and returned linearly to the initial state within 2 minutes, holding 1 minute before the next injection. The use of ammonium acetate $5 \mathrm{mM}$ in HPLC grade water as eluent $\mathrm{A}$ and $\mathrm{ACN}$ as eluent $B$ promote the negative ion mode analysis (ESI-).

The analytical method used the mass analyzer 3200 QTRAP $^{\oplus}$ (hybrid triple quadrupole-ion trap) with the TurboVTM source utilized the electrospray (ESI) at positive and negative mode to promoting the compound ionization. The analyses results were at the Standards solutions of each compound $\left(1.0 \mathrm{mg} \mathrm{L}^{-1}\right)$ into the mass spectrometer at the flow rate of $10 \mathrm{~mL} \mathrm{~min}^{-1}$. In the MRM mode, the mass analyzers Q1 and Q3 selected the precursor and product ions, respectively, defining a particular $\mathrm{m} / \mathrm{z}$ transition. The chosen transitions were MRM for each analyzed compound; the quantification used the most intense one, the confirmation process used the second. The Five-point calibration curve promotes the concentrations results in matrix generated for each compound.

Linearity, limit of detection (MDL), limit of quantification (MQL), precision, accuracy, and recovery were the parameters to evaluate the performance of the SPE-LC-MS/MS methodology. The linearity was determined by 3 injections of 5 standard mixture solutions in the matrix, with concentrations in the range from 0.2 to $500 \mathrm{ng} \mathrm{mL}^{-1}$, which corresponds to 0.2 to $500 \mathrm{ng} \mathrm{L}^{-1}$ in water samples, taking into account the 1000-fold pre-concentration factor applied along the sampling procedure. Calibration curves of the compounds showed satisfactory determination coefficients $\left(0.99 \leq \mathrm{r}^{2} \leq 1\right)$.

The deviation of 7 injections of standard mixture solutions in the matrix at the lowest calibration curve concentration multiplied by 2.447 (Student-t, 6 degrees of freedom and $90 \%$ of confidence) result in the detection limit (MDL). The average value result for 7 injections of the standard mixture at lowest concentration plus 5 times of standard deviation represents the quantification limit method (MQL). MDL and MQL ranged from 0.04 to $6 \mathrm{ng} \mathrm{L}^{-1}$ and 0.28 to $43 \mathrm{ng}$ $\mathrm{L}^{-1}$, respectively. The SPE extraction recoveries were obtained in the range from $55 \%$ to $105 \%$, only for acetaminophen, the recoveries were in the range of $12 \%$ 
to $38 \%$. The evaluation of the analytical method accuracy used the variation coefficient (CV\%) of the 7 injections of standard solutions mixture in the matrix in the middle of the concentration range of the calibration curve. The achievement for all compounds, CV\% was in the range of $2 \%$ to $7 \%$, recommended for trace analysis [14]. Therefore, the tailored analytical methodology SPE-LC-MS/MS is highly reliable for contaminated water samples mostly for such 7 selected pharmaceuticals compounds determination.

\section{Results and Discussion}

The application of SPE-LC-MS/MS a validated method to measure 7 pharmaceuticals compounds in Guarapiranga waters collected from 14 sampling sites, Table 2. The compounds were determined in triplicate and accompanied by the expanded uncertainty calculated by EURACHEM Guidelines [15] with coverage factor $(\mathrm{k}=2)$ and confidence level (90\%).

The detection frequency was $100 \%$ for caffeine, followed by atenolol (98\%), carbamazepine (95\%), benzoylecgonine (93\%), chlorthalidone (83\%), cocaine (76\%) the detection frequency was lower than $74 \%$ for other pharmaceuticals, some of them below MLD or between MLD and MLQ. In 2011, all IRICAP results of sampling sites showed the higher pharmaceuticals content with the tendency to reduce as years pass until 2013 (Figure 3). The higher pharmaceuticals concentrations were obtained for G12, as expected for a highly polluted site, considering the geographical location near Guavirutuba stream. Published works confirm the unplanned urban grow affects the water quality and the comparison of contaminated G12. The monitoring results of G05 of Jaceguay stream located in an environmental preserved area of Guarapiranga basin provided information about the possible and feasible target for Guarapiranga water restoration.

The G14 site was the nearest sampling site from water catchment. In spite of polluted G12 proximity, the G14 showed lower concentrations of acetaminophen, atenolol, benzoylecgonine, and caffeine (Table 2). There is some contamination effect, but the infrastructure improvements near G14 reduced such impact, the sewage collection pipes installation which provides the water flow

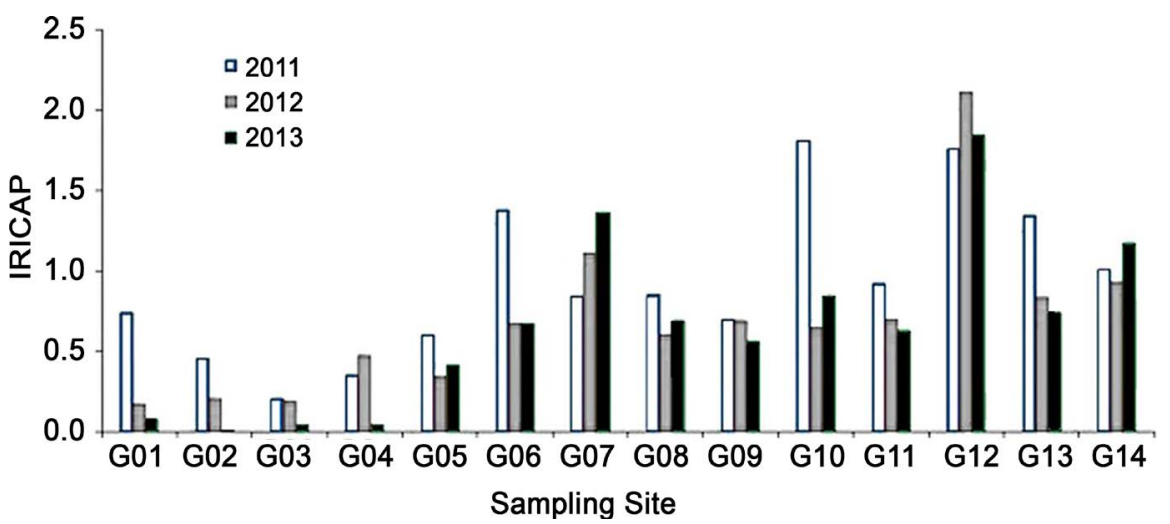

Figure 3. The integrated risk index of aquatic chemical pollution (IRICAP) of 14 sampling sites in Guarapiranga reservoir measured in 2011, 2012 and 2013. 
Table 2. The pharmaceuticals concentrations and the estimated uncertainty.

\begin{tabular}{|c|c|c|c|c|c|c|c|c|}
\hline \multirow{2}{*}{ Site } & & \multicolumn{3}{|c|}{ Concentration $\left(\mathrm{ng} \mathrm{L}^{-1}\right)$} & \multirow{2}{*}{ Caffeine } & \multirow{2}{*}{ Carbamazepine } & \multirow{2}{*}{ Chlorthalidone } & \multirow{2}{*}{ Cocaine } \\
\hline & & Acetaminophen & Atenolol & Benzoylecgonine & & & & \\
\hline \multirow[t]{3}{*}{ G01 } & 2011 & $190 \pm 15$ & $33 \pm 2$ & $11.9 \pm 0.8$ & $381 \pm 12$ & $13 \pm 1$ & $<$ MLQ & $97 \pm 5$ \\
\hline & 2012 & $<$ MLQ & $23 \pm 1$ & $<$ MLQ & $108 \pm 12$ & $<$ MLQ & $<$ MLQ & $19 \pm 1$ \\
\hline & 2013 & $<$ MLQ & $<$ MLQ & $<$ MLQ & $71 \pm 8$ & $<$ MLQ & $<$ MLD & $26 \pm 2$ \\
\hline \multirow[t]{3}{*}{ G02 } & 2011 & $254 \pm 18$ & $34 \pm 2$ & $18.7 \pm 0.6$ & $6017 \pm 33$ & $13 \pm 1$ & $9.4 \pm 0.5$ & $114 \pm 6$ \\
\hline & 2012 & $19 \pm 1$ & $17.1 \pm 0.8$ & $8.7 \pm 0.3$ & $223 \pm 25$ & $12 \pm 1$ & $<$ MLQ & $41 \pm 3$ \\
\hline & 2013 & $<\mathrm{MLD}$ & $8.5 \pm 0.4$ & $<$ MLQ & $43 \pm 6$ & $25 \pm 3$ & $<$ MLQ & $<$ MLQ \\
\hline \multirow[t]{3}{*}{ G03 } & 2011 & $45 \pm 3$ & $31 \pm 2$ & $21 \pm 2$ & $76 \pm 3$ & $16 \pm 1$ & $10.6 \pm 0.5$ & $73 \pm 3$ \\
\hline & 2012 & $13 \pm 1$ & $22 \pm 1$ & $21.0 \pm 0.6$ & $81 \pm 9$ & $29 \pm 3$ & $9.5 \pm 0.8$ & $23 \pm 2$ \\
\hline & 2013 & $<$ MLD & $10.1 \pm 0.4$ & $7.9 \pm 0.3$ & $36 \pm 4$ & $28 \pm 4$ & $<$ MLQ & $22 \pm 2$ \\
\hline \multirow[t]{3}{*}{ G04 } & 2011 & $24 \pm 2$ & $34 \pm 2$ & $25 \pm 2$ & $27 \pm 2$ & $21 \pm 3$ & $13.3 \pm 0.9$ & $21 \pm 1$ \\
\hline & 2012 & $<$ MLQ & $22 \pm 1$ & $26 \pm 1$ & $44 \pm 3$ & $49 \pm 2$ & $12.7 \pm 0.9$ & $<$ MLQ \\
\hline & 2013 & $<\mathrm{MLD}$ & $9.8 \pm 0.6$ & $8.9 \pm 0.8$ & $27 \pm 2$ & $31 \pm 4$ & $<$ MLQ & $<$ MLQ \\
\hline \multirow[t]{3}{*}{ G05 } & 2011 & $59 \pm 4$ & $64 \pm 3$ & $38 \pm 2$ & $92 \pm 10$ & $27 \pm 3$ & $18.2 \pm 0.9$ & $112 \pm 4$ \\
\hline & 2012 & $<$ MLQ & $22 \pm 1$ & $26.9 \pm 0.8$ & $47 \pm 4$ & $45 \pm 2$ & $13.9 \pm 0.8$ & $<$ MLQ \\
\hline & 2013 & $<$ MLQ & $18.3 \pm 0.8$ & $16 \pm 1$ & $59 \pm 5$ & $164 \pm 15$ & $<$ MLQ & $35 \pm 3$ \\
\hline \multirow[t]{3}{*}{ G06 } & 2011 & $48 \pm 3$ & $115 \pm 8$ & $104 \pm 7$ & $6316 \pm 143$ & $33 \pm 4$ & $34 \pm 2$ & $277 \pm 10$ \\
\hline & 2012 & $13 \pm 1$ & $44 \pm 2$ & $58 \pm 3$ & $80 \pm 9$ & $121 \pm 3$ & $22 \pm 1$ & $94 \pm 8$ \\
\hline & 2013 & $<$ MLQ & $30 \pm 1$ & $21 \pm 1$ & $51 \pm 5$ & $204 \pm 30$ & $10.6 \pm 0.5$ & $44 \pm 3$ \\
\hline \multirow[t]{3}{*}{ G07 } & 2011 & $109 \pm 8$ & $77 \pm 5$ & $41 \pm 2$ & $239 \pm 27$ & $33 \pm 4$ & $28 \pm 2$ & $137 \pm 4$ \\
\hline & 2012 & $78 \pm 5$ & $52 \pm 2$ & $71 \pm 4$ & $465 \pm 16$ & $140 \pm 3$ & $22 \pm 1$ & $197 \pm 8$ \\
\hline & 2013 & $108 \pm 9$ & $37 \pm 2$ & $29 \pm 2$ & $423 \pm 18$ & $305 \pm 41$ & $14.4 \pm 0.8$ & $70 \pm 3$ \\
\hline \multirow[t]{3}{*}{ G08 } & 2011 & $75 \pm 4$ & $76 \pm 5$ & $41 \pm 2$ & $220 \pm 25$ & $32 \pm 4$ & $27 \pm 2$ & $220 \pm 9$ \\
\hline & 2012 & $13.1 \pm 0.7$ & $18 \pm 1$ & $42 \pm 1$ & $85 \pm 10$ & $139 \pm 3$ & $22 \pm 1$ & $74 \pm 5$ \\
\hline & 2013 & $16.0 \pm 0.9$ & $22 \pm 1$ & $22 \pm 1$ & $189 \pm 11$ & $264 \pm 36$ & $11.6 \pm 0.6$ & $<$ MLQ \\
\hline \multirow[t]{3}{*}{ G09 } & 2011 & $29 \pm 2$ & $71 \pm 5$ & $36 \pm 2$ & $72 \pm 8$ & $32 \pm 4$ & $28 \pm 2$ & $125 \pm 4$ \\
\hline & 2012 & $12 \pm 1$ & $23 \pm 1$ & $40 \pm 1$ & $67 \pm 8$ & $149 \pm 4$ & $19 \pm 1$ & $<$ MLQ \\
\hline & 2013 & $16 \pm 1$ & $23 \pm 1$ & $15.4 \pm 0.9$ & $265 \pm 14$ & $296 \pm 38$ & $12.2 \pm 0.6$ & $32 \pm 2$ \\
\hline \multirow[t]{3}{*}{ G10 } & 2011 & $12.8 \pm 0.7$ & $107 \pm 6$ & $86 \pm 5$ & $17416 \pm 90$ & $34 \pm 4$ & $29 \pm 2$ & $314 \pm 13$ \\
\hline & 2012 & $12.0 \pm 0.8$ & $17.2 \pm 0.8$ & $53 \pm 3$ & $200 \pm 23$ & $116 \pm 3$ & $23 \pm 2$ & $<$ MLQ \\
\hline & 2013 & $33 \pm 3$ & $28 \pm 1$ & $22 \pm 1$ & $210 \pm 15$ & $259 \pm 32$ & $12.0 \pm 0.6$ & $25 \pm 2$ \\
\hline \multirow[t]{3}{*}{ G11 } & 2011 & $46 \pm 3$ & $79 \pm 6$ & $35 \pm 2$ & $236 \pm 27$ & $34 \pm 4$ & $28 \pm 2$ & $104 \pm 4$ \\
\hline & 2012 & $12.0 \pm 0.8$ & $14.3 \pm 0.6$ & $41 \pm 2$ & $75 \pm 8$ & $148 \pm 4$ & $16,5 \pm 0,9$ & $<\mathrm{MLD}$ \\
\hline & 2013 & $18 \pm 2$ & $24 \pm 1$ & $18 \pm 1$ & $248 \pm 15$ & $314 \pm 39$ & $12.7 \pm 0.7$ & $18 \pm 1$ \\
\hline \multirow[t]{3}{*}{ G12 } & 2011 & $91 \pm 6$ & $116 \pm 9$ & $60 \pm 5$ & $12019 \pm 65$ & $33 \pm 4$ & $33 \pm 2$ & $512 \pm 18$ \\
\hline & 2012 & $<$ MLQ & $177 \pm 5$ & $139 \pm 7$ & $313 \pm 35$ & $149 \pm 4$ & $35 \pm 2$ & $2650 \pm 28$ \\
\hline & 2013 & $73 \pm 7$ & $70 \pm 3$ & $42 \pm 3$ & $27386 \pm 142$ & $277 \pm 35$ & $14.7 \pm 0.7$ & $261 \pm 8$ \\
\hline \multirow[t]{3}{*}{ G13 } & 2011 & $192 \pm 16$ & $95 \pm 6$ & $67 \pm 4$ & $7776 \pm 176$ & $37 \pm 4$ & $33 \pm 2$ & $257 \pm 8$ \\
\hline & 2012 & $9.6 \pm 0.7$ & $15.2 \pm 0.7$ & $33 \pm 2$ & $98 \pm 11$ & $152 \pm 4$ & $21 \pm 1$ & $<$ MLQ \\
\hline & 2013 & $16 \pm 1$ & $21 \pm 1$ & $16.7 \pm 0.8$ & $310 \pm 21$ & $358 \pm 44$ & $14.5 \pm 0.7$ & $19 \pm 1$ \\
\hline \multirow[t]{3}{*}{ G14 } & 2011 & $38 \pm 2$ & $73 \pm 6$ & $59 \pm 4$ & $253 \pm 28$ & $32 \pm 4$ & $32 \pm 2$ & $95 \pm 3$ \\
\hline & 2012 & $<$ MLQ & $11.0 \pm 0.5$ & $31 \pm 1$ & $107 \pm 12$ & $150 \pm 4$ & $21 \pm 1$ & $<$ MLQ \\
\hline & 2013 & $15 \pm 2$ & $24 \pm 1$ & $16.7 \pm 0.5$ & $302 \pm 18$ & $327 \pm 41$ & $14.2 \pm 0.9$ & $12.8 \pm 0.8$ \\
\hline
\end{tabular}


increase, water clogging reduction and higher water column depth (Figure 1 and Table 1).

The compounds concentrations in G14, near water catchment, were smaller than those measured in G12. However, it doesn't mean the complete absence of these compounds in drinking water (Table 2). According to the literature, the removal rate of pharmaceuticals by a conventional water treatment plant-WTP (clarification/filtration/chlorination) is somewhat not complete. In literature, the acetaminophen, caffeine and carbamazepine content reduction are usually about $98 \%, 88 \%$, and $85 \%$, respectively [11].

Sewage and urban drainage are considered the source of anthropogenic contamination and the caffeine presence is their indication. The measured concentrations were in the range of 27 to $27,386 \mathrm{ng} \mathrm{L}^{-1}$ confirming the existence of raw sewage discharge. The caffeine contamination was detected globally, in Germany surface waters was measured $101 \mathrm{ng} \mathrm{L}^{-1}$ [8] and in Atibaia River was in the range of 6000 to $32,000 \mathrm{ng} \mathrm{L}^{-1}$ [16].

Carbamazepine is the active medicine component and an anthropogenic marker due to its persistence, resistance to degradation and adsorption during sewage treatment plants (STP) processes. The conventional STP is responsible for the presence of this compound in water resources. The values were in the range of 12 to $358 \mathrm{ng} \mathrm{L}^{-1}$ in Guarapiranga reservoir (Table 2), equivalent with those found in the literature for River Leine in Germany of $265 \mathrm{ng} \mathrm{L}^{-1}$ [8].

The Table 3 is a correlation table prepared using the experimental results and presents a correlation between the compounds content of chlorthalidone, atenolol, benzoylecgonine, caffeine, and cocaine. The chlorthalidone, caffeine and atenolol content were in direct correlation as an indication of anthropogenic urban pollution by raw sewage discharge and urban drainage. The relation between cocaine and benzoylecgonine was a significant evidence of the cocaine was used for human consumption with direct indication of sewage discharge by chlorthalidone correlation.

The chlorthalidone is an antihypertensive and responsible by increasing in volume degree of urinary flow and dilatation of blood vessel. The quantification of the chlorthalidone in concentrations of 9.4 to $35 \mathrm{ng} \mathrm{L}^{-1}$ is a pioneer monitoring

Table 3. Correlation table of pharmaceuticals in Guarapiranga water samples.

\begin{tabular}{cccccccc}
\hline & Acetaminophen & Atenolol & Benzoylecgonine & Caffeine & Carbamazepine & Chlorthalidone & Cocaine \\
\hline Acetaminophen & 1 & & & & & & \\
Atenolol & 0.26 & 1 & & & & & \\
Benzoylecgonine & 0.07 & 0.85 & 1 & & & & \\
Caffeine & 0.28 & 0.43 & 0.32 & 1 & 1 & 1 & 0.02 \\
Carbamazepine & 0.20 & 0.18 & 0.05 & 0.04 & 0.25 & 0.01 & 1 \\
Chlorthalidone & 0.07 & 0.84 & 0.83 & 0.71 & 0.14 & 0.01 & \\
Cocaine & 0.01 & 0.74 & 0.71 & & \\
\hline
\end{tabular}


data for Guarapiranga basin. Chlorthalidone occurrence reports in Guarapiranga basin were also not found in the literature yet.

Published works relate high concentrations of acetaminophen in surface waters, influent, effluent and from the sewage as observed in this project. The water samples collected in Guarapiranga basin have the acetaminophen in the range of 9.6 to $254 \mathrm{ng} \mathrm{L}^{-1}$ similar with those found in surface water in Campinas Metropolitan Region, SP (of $840 \mathrm{ng} \mathrm{L}^{-1}$ ), and Billings Dam in the range of 8.1 to 394.5 ng $\mathrm{L}^{-1}$ [16] [17]. In spite of such high concentrations, the sewage runoff has not any significant correlation with caffeine and chlorthalidone content.

Cocaine drug causes a dysfunctional social order, and benzoylecgonine is its primary metabolite. In last decades, the cocaine consumption has been growing globally with significant socioeconomic consequences with the health assurance cost increasing and criminal incidences [18] [19] [20]. The detection of pharmaceuticals compounds, drugs residues, and their metabolites are considered environmental emerging pollutants in the aquatic environment [21]. The measurements for cocaine were in the range of 12.8 to $2650 \mathrm{ng} \mathrm{L}^{-1}$. Such values were higher than those found in surface waters in China [22], Spain [23], England, Italy, Ireland [24] and the UK [21], which was in the range of 0.13 to $530 \mathrm{ng} \mathrm{L}^{-1}$. The cocaine concentrations found in the Guarapiranga reservoir waters were maximum in sampling site (G12) in 2012. The benzoylecgonine was in the range of 7.9 to 139 $\mathrm{ng} \mathrm{L} \mathrm{L}^{-1}$. The Cocaine and benzoylecgonine concentrations are in direct correlation, a clear indication of drug abuse and the presence of domestic sewage runoff higher in G12, near Guavirutuba stream.

All campaigns of Guarapiranga waters collection shows different concentrations of acetaminophen, atenolol, caffeine, carbamazepine, chlorthalidone, cocaine and benzoylecgonine mostly observed in G12. The confirmation of the highly polluted Guavirutuba site due to its historical profile, as the first step of the urban pressure on 30 ties with inadequate sewage collection and the contribution of pollution intake [24].

The presence of cocaine and its major metabolite benzoylecgonine in tree water sampling points of Guarapiranga basin was also recently related in literature; almost all measurements performed near urban areas shows values for benzoylecgonine and cocaine [25]. Such monitoring water content was considered a result of poor sanitation coverage and high consumption and abuse drugs in urban areas, possibly an indication of social vulnerability. The published work shows a comparison of Guarapiranga water content during the wet season from February to March and the dry season from September to October performed in 2014. The Benzoylecgonine was related to being in the range of $17 \mathrm{ng} \mathrm{L}^{-1}$ to $179 \mathrm{ng} \mathrm{L}^{-1}$ and detected in $94 \%$ of the water samples with concentrations above LOD (bellow of observed detection limit= LOD). The discovery of the cocaine content was in the range of $10 \mathrm{ng} \mathrm{L}^{-1}$ to $12 \mathrm{ng} \mathrm{L}^{-1}$ for $85 \%$ of the total water samples with concentrations lower than LOD [25] [26]. All measured values of 2012 were higher than published work for 2014, the transposition of Taquacetuba affects the results of Guarapiranga sampling sites in some degree with water quality improvement by 
the end of 2012. The transposition promotes the connection between Billings dam and Guarapiranga basin enhancing the water volume and also the water quality by dilution [25] [27].

The sampling site G05 near Jaceguay stream can be considered the most preserved area. The Table 2 present the monitoring results for Acetaminophen 59 $\mathrm{ng} \mathrm{\textrm {L } ^ { - 1 }}$, atenolol in the interval of 18.3 to $64 \mathrm{ng} \mathrm{L}^{-1}$, benzoylecgonine in the interval of 16 to $38 \mathrm{ng} \mathrm{L}^{-1}$, caffeine in the range of 47 to $92 \mathrm{ng} \mathrm{L}^{-1}$. For carbamazepine was from 27 to $164 \mathrm{ng} \mathrm{L}^{-1}$, chlorthalidone in the range of 13.9 to $18.2 \mathrm{ng} \mathrm{L}^{-1}$ and cocaine in the interval of 35 to $112 \mathrm{ng} \mathrm{L}^{-1}$ the values can be considered acceptable for the first step of the practical and feasible water quality restoration.

The climate change effects have also been observed in Guarapiranga basin and metropolitan area of São Paulo, in recent years with the drastic reduction of water raining volume, even during the raining season. The Guarapiranga water recharge shows a significant influence of Sea Mountains and Atlantic Ocean humidity which increases the total moisture content. This effect is peculiar of its geographical location and differs from others water reservoirs located in an inner part of the Sao Paulo State. Recently the state government has developed some programs which include the sewage collection improvement on urbanized areas and the implementation of ultrafiltration systems trying to perform the Guarapiranga water quality restoration and maintenance as a rain independent water resource, precious to be used now and in the near future.

\section{Conclusion}

The project provides valuable pharmaceuticals contamination databank of Guarapiranga Reservoir with the identification and quantification of 7 most concentrated compounds. The study documented an evident water quality loss near Guavirutuba tributary; the comparison with the historical urbanization profile highlights the polluted tributary as the first urbanization step, still, the high contamination source which favors the water quality loss and increases the water treatment cost. The comparison results of Guavirutuba and Jaceguay stream point out the possible target for Guarapiranga water restoration searched by politicians, government, and users. The IRICAP indicates the integrated exposure risk to the pharmaceuticals mixture, the most polluted points were obtained for G10 to G14, pointing out G12 as the high pollution source near Guavirutuba stream, and G05 the most preserved area near Jaceguay stream. The presence of emerging pollutants such as pharmaceuticals, illicit drug (cocaine) and benzoylecgonine (metabolite) is a significant concern with their appearance in domestic sewage discharge, performing a complex mixture of several stable and persistent compounds, demanding of the water treatment high level of complexity and cost. The Jaceguay values will represent the first step for water restoration projects, a possible and feasible water quality target. The content of cocaine and its metabolite in Guarapiranga dam is corroborated by recently published works, which include some stream and Rivers located near high urbanized metropolitan areas. Such information is inva- 
luable to assist public policies responsible for potable water distribution, social vulnerability studies, the sewage collection system implementation and programs to restore and preserve the water quality of Guarapiranga dam. New standards and guidelines have also to be improved to reduce the maximum discharge limits of pharmaceuticals in drinking water and water catchment.

\section{Acknowledgements}

FAPESP (São Paulo Research Foundation) projects: 2009/53898-9 and 2011/51064-3, CNPq ((National Counsel of Technological and Scientific Development) project: 310214/203-0 and São Paulo water supply company, SABESP/RHMS (Companhia de Saneamento do Estado de São Paulo, Divisão de Recursos Hídricos Metropolitano Sudoeste).

\section{References}

[1] IBGE Brasilian Institute of Geography and Statistics (2014) Population Estimates for the Brazilian Municipalities in 07.01.2014. http://www.ibge.gov.br/english/estatistica/populacao/estimativa2014/

[2] Richter, E.M., Fornaro, A., Lago, C.L. and Angnes, L. (2007) Evaluation of the Chemical Composition of the Guarapiranga Water System: Case Study (2002 and 2003). Química Nova, 30, 1147-1152. https://doi.org/10.1590/S0100-40422007000500018

[3] Leite, F. (2015) SP Already Depends More of the Guarapiranga. Newspaper. (In Portuguese)

http://http://sao-paulo.estadao.com.br/noticias/geral,sp-ja-depende-mais-do-guarap iranga, 1647587

[4] Silva, J.P. (2005) Expansão urbana e evolução geomorfológica em remansos de reservatórios: análise comparativa de duas bacias hidrográficas em Guarapiranga, São Paulo. [Urban Expansion and Geomorphological Evolution in Reservoir Tributaries: Comparative Analysis of the Two Urban Stream in Guarapiranga Reservoir, São Paulo.] Master’s Dissertation, University of São Paulo, São Paulo, 129 p.

[5] Machado, K.C., Grassi, M.T., Vidal, C., Pescara, I.C., Jardim, W.F., Fernandes, A.N., Sodre, F.F., Almeida, F.V., Santana, J.S., Canela, M.C., Nunes, C.R.O., Bichinho, K.M. and Severo, F.J.R. (2016) A Preliminary Nation Wide Survey of the Presence of Emerging Contaminants in Drinking and Source Waters in Brazil. Science of the Total Environment, 572, 138-146. https://doi.org/10.1016/j.scitotenv.2016.07.210

[6] Lopez-Doval, J.C., Montagner, C.C., Albuquerque, A.F., Moschini-Carlos, V., Umbuzeiro, G. and Pompeo, M. (2017) Nutrients, Emerging Pollutants and Pesticides in a Tropical Urban Reservoirf: Spatial Distributions and Risk Assessment. Science of the Total Environment, 575, 1307-1324. https://doi.org/10.1016/j.scitotenv.2016.09.210

[7] Ikematsu, P. (2014) Conflitos e desafios na gestão da bacia Hidrográfica do Reservatório Guarapiranga. [Conflicts and Challenges of Guarapiranga Basin Reservoir Management.] Master's Dissertation, São Paulo University, São Paulo, 208 p.

[8] Nódler, K., Licha, T., Bester, K. and Sauter, M. (2010) Development of a Multi-Residue Analytical Method, Based on Liquid Chromatography-Tandem Mass Spectrometry, for the Simultaneous Determination of 46 Micro-Contaminants in Aqueous Samples. Journal of Chromatography A, 1217, 6511-6521. 
https://doi.org/10.1016/j.chroma.2010.08.048

[9] Houtman, C.J., Kroesbergen, J., Lekkerkerker-Teunissen, K. and van der Hock, J.P. (2014) Human Health Risk Assessment of the Mixture of Pharmaceuticals in Dutch Drinking Water and Its Sources Based on Frequent Monitoring Data. Science of the Total Environment, 496, 54-62. https://doi.org/10.1016/j.scitotenv.2014.07.022

[10] Mulroy, A. (2001) When the Cure Is the Problem: Antibiotic Contamination of Surface Water and Groundwater May Be Promoting the Development of Drug-Resistant Pathogen. Water \& Environmental Technologies, 13, 32-36.

[11] Stackelerg, P.E., Furlong, E.T., Meyer, M.T., Zaugg, S.D., Henderson, A.K. and Reissman, D.B. (2004) Persistence of Pharmaceutical Compounds and Other Organic Wastewater Contaminants in a Conventional Drinking Water Treatment Plant. Science of the Total Environment, 329, 99-113.

https://doi.org/10.1016/j.scitotenv.2004.03.015

[12] Rodriguez-Mozaz, S., Alda, M.J.L. and Barceló, D. (2007) Advantages and Limitations of On-Line Solid Phase Extraction Coupled to Liquid Chromatography-Mass Spectrometry Technologies versus Biosensors for Monitoring of Emerging Contaminants in Water. Journal of Chromatography A, 1152, 97-115.

https://doi.org/10.1016/j.chroma.2007.01.046

[13] Fàbrega, F., Marquès, M., Ginebreda, A., Kuzmanovic, M., Barceló, D., Schuhmacher, M., Domingo, J.L. and Nadal, M. (2013) Integrated Risk Index of Chemical Aquatic Pollution (IRICAP): Case Studies in Iberian Rivers. Journal of Hazardous Materials, 263, 187-196. https://doi.org/10.1016/j.jhazmat.2013.06.006

[14] Horwitz, W. and Albert, R. (2006) The Horwitz Ratio (HorRat): A Useful Index of Method Performance with Respect to Precision. Journal of AOAC International, 89, 1095-1109.

[15] EURACHEM/CITAC (2012) Quantifying Uncertainty in Analytical Measurement. 3rd Edition, EURACHEM/CITAC.

[16] Sodré, F.F., Montagner, C.C., Locatelli, M.A.F. and Jardim, W.F. (2007) Occurrences of Endocrine Disrupting Chemical and Pharmaceuticals Products in Surface Freshwater from Campinas Region (SP, Brazil). Journal of the Brazilian Society of Ecotoxicology, 2, 187-196. (In Portuguese) https://doi.org/10.5132/jbse.2007.02.012

[17] Almeida, G.A. and Weber, R.R. (2005) Pharmaceuticals in Billings Dam. Revista Saúde e Ambientel Health and Environment Journal, 6, 7-13. (In Portuguese)

[18] Garcia-Galán, M.J., Díaz-Cruz, M.S. and Barceló, D. (2010) Determination of 19 Sulfonamides in Water Samples by Automated On-Line Solid-Phase Extraction-Liquid Chromatography-Tandem Mass Spectrometry (SPE-LC-MS/MS). Talanta, 81, 355-366. https://doi.org/10.1016/j.talanta.2009.12.009

[19] UNODC United Nations Office on Drugs and Crime (2015) World Drug Report 2015. United Nation, New York.

[20] Shihomatsu, H.M. (2015) Development and Validation of Methodology SPE-LC-MS/MS for Pharmaceuticals and Illicit Drug Determination in Guarapiranga Reservoir Waters-São Paulo/SP, Brazil. Masters Dissertation, São Paulo University, Nuclear and Energy Research Institute, São Paulo. (In Portuguese)

[21] Baker, D.R. and Krasprzyk-Hordern, B. (2011) Multi-Residue Analysis of Drugs of Abuse in Wastewater and Surface Water by Solid-Phase Extraction and Liquid Chromatography-Positive Electrospray Ionization Tandem Mass Spectrometry. Journal of Chromatography A, 1218, 1620-1631. https://doi.org/10.1016/j.chroma.2011.01.060

[22] Lin, A.Y.-C., Wang, X.-H. and Lin, C.-F. (2010) Impact of Wastewaters and Hospit- 
al Effluents on the Occurrence of Controlled Substances in Surface Waters. Chemosphere, 81, 562-570. https://doi.org/10.1016/j.chemosphere.2010.08.051

[23] Bueno, M.J.M., Uclés, S., Hernando, M.D. and Fernández-Alba, A.R. (2011) Development of a Solvent-Free Method for the Simultaneous Identification/Quantification of Drugs of Abuse and Their Metabolites in Environmental Water by LC-MS/MS. Talanta, 85, 157-166. https://doi.org/10.1016/j.talanta.2011.03.051

[24] Bones, J., Thomas, K.V. and Paull, B. (2007) Using Environmental Analytical Data to Estimate Levels of Community Consumption of Illicit Drugs and Abused Pharmaceuticals. Journal of Environmental Monitoring, 9, 701-707. https://doi.org/10.1039/b702799k

[25] SMA Secretariat of the Environment Sao Paulo's State Government (2013) Update of the Development Plan and Environmental Protection (APRM) Basin of Guarapiranga. Final Report. (In Portuguese)

http://www.ambiente.sp.gov.br/cpla/2013/03/14/aprm-area-de-protecao-e-recupera cao-de-mananciais/

[26] Campestrini, I. and Jardim, W.F. (2017) Occurrence of Cocaine and Benzoylecgonine in Drinking and Source Water in the São Paulo State Region, Brazil. Science of Total Environment, 576, 374-380.

https://doi.org/10.1016/j.scitotenv.2016.10.089

[27] World Water Council (2017) World Water Forum. http://www.ambiente.sp.gov.br/pactodasaguas/mananciais 